\title{
The Muqtadhal Haal Da'wah of K.H. Dalhar and Its Relevance in Modern Society
}

\author{
Muslichatul Rodiyah, S. Ag., M.Pd. I \\ Doctoral Program in Islamic Studies \\ UIN Sunan Kalijaga Yogyakarta, Indonesia \\ E-mail: lihahawi@gmail.com \\ Dudung Abdurahman, M. Hum. \\ Postgraduate Lecturer \\ UIN Sunan Kalijaga Yogyakarta, Indonesia \\ E-mail: durahman.uin@gmail.com \\ Andy Dermawan, MA \\ Postgraduate Lecturer \\ UIN Sunan Kalijaga Yogyakarta, Indonesia \\ E-mail: Andydermawan70@gmail.com
}

Received: Dec. 29, 2021 Accepted: Feb. 15, 2022 Published: March 6, 2022

doi:10.5296/ijssr.v10i1.19400ＵRL: https://doi.org/10.5296/ijssr.v10i1.19400

\begin{abstract}
This study seeks to explore the format of the Muqtadhal Haal da'wah of Kiai Dalhar and its implementation and relevance for modern society. The research uses a historical and socio-anthropological approach, referring to Clifford Geertz's "thick description" theory and Habermas' "communication" theory. The research was conducted using the historical method. The results show that the Muqtadhal Haal da'wah is a da'wah that is carried out through communication actions that are built by placing the dai (Islamic preacher) and da'wah targets in an equal position. A dai does not deliver the da'wah material orally before the da'wah targets ask. A dai in delivering his da'wah will try to adapt the materials, methods and media to the psychological, sociological, anthropological and intellectual capacities of the da'wah targets.
\end{abstract}




\section{Macrothink}

International Journal of Social Science Research

ISSN 2327-5510 2022, Vol. 10, No. 1

Da'wah is not carried out in a harsh, rigid and revolutionary way, on the contrary, it is carried out in a polite, gentle, touching manner, and proceeds according to the circumstances of the da'wah targets. The implementation of da'wah applies transcendental, contextual, sentimental and harmonization strategies. The dialectic of democratic communication in the application of the Muqtadhal Haal Kiai Dalhar's da'wah is very effective in the development of Islam in Central Java, so that the da'wah model can be used as an alternative to da'wah in modern society today.

Keywords: Muqtadhal Haal Da’wah, Kiai Dalhar, modern society 


\section{Introduction}

The phenomenon that has emerged in Indonesia since the 1980s shows many actors in the Islamic movement whose way of preaching or da'wah (Izudin, 2018) is different from that of Sufi scholars and Walisanga. Those Islamic movements are Tarbiyah, Hizbu at-Tahrir, Majelis Mujāhidin, Front Pembela Islam and Laskar Jihad. These organizations have ideological bases, ideas and movement strategies that are different from previous mass organizations and are also different from the way of preaching of Sufi scholars and Walisanga. They are suspected to be puritanical, and they have more militant, radical, scriptural, conservative and exclusive characters. Their platforms are diverse but they share a common vision, namely the establishment of an Islamic State "Daulah Islamiyah" and realizing the application of Islamic law in the state government's form and system (Rahmad, 2005). The influence is that there are certain elements among the Muslim community, especially the ulama (scholars) who wish to accelerate the process of Islamization by encouraging the population to do their best to abandon all un-Islamic religious beliefs and practices. The continued incompatability of Islamic values and teachings which are seen as genuine and authentic in their version provides the main reason for some ulama to carry out religious reforms even in harsh, radical and revolutionary ways (Azra, 2002).

In addition, da'wah carried out individually or institutionally still shows personal and group egoism. They fight other groups whom they considered to have committed religious deviations (Rosidi, 2013). The crucial problem that also hinders the dynamics of da'wah is the difference in understanding that causes communication between them to be distant, even showing egoism that develops into conflict. The problems that arise as a result of these differences occur not only internally in Islam, but also in other religions, including in inter-religious relations that experience ups and downs. The problem of da'wah is an undeniable fact (Rosidi, 2013). This phenomenon confirms that the practice of da'wah in Indonesia is still characterized by inequality and has not yet implemented Islam as the religion of rahmatan lil'alamin (mercy for the whole world). The da'wah that has been carried out has not fully paid attention to the psychological, sociological, anthropological and intellectual capacities of the da'wah targets.

The problems of da'wah above have encouraged Muslim scholars to formulate the format of da'wah as a solution. Nurcholish Madjid offers the idea of "Madaniah" da'wah or "Civil society" da'wah by formulating religious messages into three main aspects, namely: Islam, modernity, and Indonesianness (Pirol, 2012); Abdurrahman Wahid responded with multicultural da'wah, namely missionary thought and movement involving friendly and peaceful respect in differences and fighting for cultural da'wah as a manifestation of Islam rahmatan lil alamin (Rosidi, 2017). Gus Dur's multicultural da'wah is based on three aspects, namely the main Islamic values, thoughts and lines of struggle. Tawheed, humanity, justice, equality, liberation, brotherhood, simplicity, chivalry and wisdom are the main Islamic values that are upheld according to the locality of society and the nation through the line of struggle for indigenization of Islam, meaning how Islam is able to accommodate the local needs (Ihsani et al., 2021).

The concept of madaniah da'wah offered by Nur Cholis Madjid is still limited to the normative 
and conceptual aspects that can only be accessed by the urban segment, the middle class such as rulers, officials, intellectuals and social institutions that act as social control and governance and do not touch traditional society segments. Gus Dur's Multicultural Da'wah is a da'wah concept that is based on sociological and anthropological conditions that have not yet touched the psychological realm and intellectual capacity. The concept is still philosophical in nature, the explanation is more on how da'wah can take place peacefully and supports the internalization of tolerance and coexistence in diverse societies. Kiai Dalhar offered a more practical and realistic concept of da'wah that can be accessed by all elements of society, from ordinary people to Islamic scholars, from traditional communities to city dwellers, and from intellectuals to officials called the Muqtadhal Haal Da'wah.

Kiai Dalhar from Watucongol Gunungpring Muntilan, Magelang Regency is an influential figure in terms of his thoughts and da'wah strategies, especially in the local context. Although only in a narrow scope (Gunungpring village), he was able to bring Islamic da'wah to all elements of society from the common people to the ulama who gave Islamic da'wah in their respective areas. Many great scholars in Java learned from him. He was very influential in his time and his influence is still felt today, as evidenced by the fact that there are many people who follow his thoughts and practice his teachings and flock to make spiritual pilgrimages to his grave. They are from various parts of the archipelago, not only from Magelang but the majority of Javanese people and even from outside Java such as Sumatra, Kalimantan and Sulawesi (Prasiswarto, 2020).

This paper presents the Da'wah of Muqtadhal Haal of Kiai Dalhar and its relevance in the modern society. It is expected that this study may bring up new perspectives in practical and realistic da'wah concepts and strategies. This study will provide a comprehensive understanding of how Kiai Dalhar conducts da'wah in a polite and gentle manner and pays attention to his da'wah targets from the psychological, sociological, anthropological and intellectual capacity aspects. The results of this study contribute to scientific development in the field of da'wah methodology and may become a guidance in carrying out da'wah. Thus it is hoped that the da'wah will succeed in attracting people's hearts to become muslim with awareness from within and without coercion.

\section{Methods}

This research is a historical research, so it uses the historical method where the procedure includes four stages, namely: Heuristics, Criticism or verification, Interpretation and Historiography (Abdurahman, 2019). The data in this study are grouped into two, namely primary data and secondary data. The primary data is obtained through documentation and in-depth interviews (Sugiono, 2009). Documentation is conducted by collecting books of Kiai Dalhar, books of the Salaf that represent his thoughts and books written by his students containing the teachings of Kiai Dalhar.

The second technique is interviews. Because the figure studied had passed away, in-depth interviews were conducted with the informants whom the researchers determined based on the consideration of the extent of their relevance to Kiai Dalhar's thoughts, among others, first, his daughter named Nyai Nur Channah Hasanah, the owner of the Pesantren Ad-Dalhariyah, who 
is known to preserve the thoughts and teachings of his father and she has a track record of da'wah carried out by kyai Dalhar; second, Mr. Prasiswarto, BSc. (KRT. Proboreksosishartoyo, BSc.), a secretary of the Kiai Raden Santri Foundation Gunungpring Muntilan and a servant in the Yogyakarta Palace (Abdi Dalem Karaton Ngayogyakarta Hadiningrat) who lives in Gunungpring sub-village. He still found the life of Kyai Dalhar until the age of nine years and he used to study at the Pesantren Darussalam and received stories about Kiai Dalhar from the leader of his pesantren.

This study uses two theories, namely the theory of Cliffort Geetz "thick description" (Geertz, 1973 ) and the theory of Habermas "action communication" (interaction is built on the basis of mutual understanding) (Hardiman, 2009). The reading to the da'wah concept of Kiai Dalhar using the theory of Cliffort Geetz "thick description" was conducted by making in-depth meanings of the documents such as the works of Kiai Dalhar, the classic books that became the curriculum in his pesantren, the book Hidāyah al-Jalāliyyah fi at-Tarïqah Al-Syaźiliyyah by Muhammad Dimyati Banten who became his disciples, and other sources and then it was synchronized with the data obtained through interviews. The reading to the implementation of Muqtadhal Haal da'wah of Kiai Dalhar in Java, and its influence on the success of Islamization in Java also used Habermas theory of "communication actions" (interactions are built on the basis of mutual understanding) on the data collected in the form of historical books that describe the sociological and anthropological conditions of Javanese society and interview results.

\section{Da'wah Concept}

In the scientific study of da'wah, there are two main materials, namely da'wah thinking and da'wah activities. Da'wah thinking is a study related to reflection on the nature of the meaning of da'wah (ontology), how da'wah is considered as a science (epistemology) and the values of da'wah (axiology), and the discussion of the da'wah dynamics from time to time. The scientific thought of da'wah is theoretical which is realized in order to build the structure of da'wah (Muhyiddin, 2014).

Da'wah activities are all activities and movements of da'wah that are realized in the real life. This activity is carried out by religious leaders, scholars, teachers, community leaders or every human being or group of people who have sensitivity, concern and a sense of responsibility in conveying Islamic teachings to others personally and to the community (Muhyiddin, 2014).

As a universal need, da'wah activities require management starting from planning, implementing and evaluating the results to realize the dynamics of da'wah in harmony with the civilization that develops in society. Through these da'wah activities, it is hoped that the vision and mission of da'wah can be achieved. Da'wah has a vision of improving the quality of human life in all aspects, while its mission is that the entire rhythm of life can run in accordance with Islamic values and the noble values of civilization that developed in society.

Da'wah in its broadest sense is inviting a person or society to act to create better conditions according to religious standards with appropriate approaches, methods and media so that it is easily accepted by many people. Da'wah is carried out based on clear goals and objectives in 
good ways. Like a doctor who wants to treat a patient, he is required to be able to diagnose the patient's disease correctly and provide appropriate therapy and drugs. A dai is expected to pay attention to da'wah targets, identify possible problems that arise, analyze them in order to be able to make solutions so that da'wah is carried out in accordance with the expected goals. From the definition of da'wah, it indicates that theoretically the components or elements of da'wah include a dai (preacher), da'wah targets, da'wah messages, methods, media and goals of da'wah (Aziz, 2009).

The important thing that a dai must not forget in order to be successful in his da'wah is to understand the da'wah strategy. Experts define strategy in different terms. According to Kustadi Suhadang, strategy is a thought process that includes simultaneous observation and concentration of attention, meaning that the strategy is carried out by observing in a focused way and carefully so that it can sort and choose more effective actions to achieve a goal (Suhadang, 2014).

According to Prof. Dr. Hamidi, M. Si:

"A strategy is a way to achieve clearly specified goals with a combination of means and a certain time period. By anticipating we try to predict what the appointment(s), one self and/or nature can do."

A strategy is the way that a person does to achieve the goals set in certain ways at a certain time by controlling and solving problems that may occur (Hamidi, 2010).

Little John defines strategy as "a plan of action" in which the methodology is termed by Burke with The Dramatistic pentad, and the details are as follows:

a. Act (action), what is done by the actor. The first component describes what actors should play, what should be done and what should be completed.

b. Scene (atmosphere), namely the situation or circumstances in which the action will take place. The second aspect includes an explanation of the physical and cultural conditions and the community environment in which the action will be carried out.

c. Agent, namely the actor himself who must and will carry out his duties, including everything he knows about its substance. The substance of the agent includes all aspects of his humanity, his attitude, his personality, his history and other related factors.

d. Agency, namely instruments or tools that will be used by actors (agents) in carrying out their actions. It can be in the form of communication channels, ways of thinking, institutions (media), messages or other related tools.

e. Purpose (intention), which is the reason for acting which includes theoretical goals, consequences or expected results from the action (Hamidi, 2010).

If it is associated with da'wah activities, da'wah strategy is defined as the design of da'wah activities in the form of determining and placing all resources that support the successful achievement of da'wah goals. In it there are various components and implementation techniques used in these activities. The determination of the components and the 
implementation of their arrangements are carried out with various considerations, which take into account the capabilities of the available resources and the situation of the da'wah environment. All these considerations require a wise action in deciding.

\subsection{The Muqtadhal Haal Da'wah}

The word 'Muqtad̄a' is masdar of fi'il madhi Iqtaḍa who got an extra letter aleph at the beginning and the letter tak on the order of the third letter that in sharaf it means Talab (demands) (Ma'sum bin Ali, n.d.). Qaḍa originally from Iqtaḍa means to conduct, to carry out, to work on, to achieve one's purpose or to get what one wants (Munawir, n.d.). Having become Iqtadā means wanting, asking, demanding. Haal means the situation. Muqtadhal Haal means according to the circumstances. So what the writer means by Muqtadhal Haal is the demand to do something according to the circumstances so that the goals and objectives are achieved.

The term Muqtadhal Haal (Akhdhori, 1982) was originally used in Arabic literature or Balaghah science which is used to describe a good communication pattern, namely when the mutakallim conveys the message of kalam to the audience by using kalam according to the circumstances of the audience. The word 'situation' here may have a broad meaning including the psychological, sociological, anthropological conditions and the intellectual capacity. Mutakallim should be able to choose words that are relevant to conditions including the length of the kalam that must be considered and adapted well to the audience, so that Kalam is delivered and is actually received by the audience.

The term Muqtadhal Haal in this paper is used to describe the da'wah that is carried out by really paying attention to the demands of the da'wah targets from the psychological, sociological, anthropological and intellectual capacity aspects. Conformity between the action, the atmosphere, the agent, the agency and what is the intent and purpose of da'wah is a necessity.

The Muqtadhal Haal Da'wah is all the efforts made by a preacher (dai) to his da'wah targets so that the values of God's noble and great teachings are known, understood, and followed and become role models in human life so as to create personal and community lives that are religious, harmonious, prosperous physically and mentally and happy in this world and in the hereafter in a way that is in accordance with the concept of religion and the state of the da'wah targets from the psychological, sociological, anthropological and intellectual capacity aspects. Da'wah cannot be carried out in a harsh, rigid and revolutionary way, on the contrary, da'wah is carried out politely, gently, touching the heart and proceeds step by step to measure the state of the da'wah targets from the psychological, sociological, anthropological and intellectual capacity aspects.

\subsection{The Concept of the Muqtadhal Haal Da'wah of K.H. Dalhar}

The concept of the Muqtadhal Haal Da'wah of K.H. Dalhar:

Da'wah is carried out through communication actions that are built by placing the dai and the da'wah targets in an equal position. A dai did not deliver the da'wah material orally before the da'wah targets asked. A dai in delivering da'wah tries to adapt materials, media and methods to 
the psychological, sociological, anthropological and intellectual capacities of the da'wah targets (Shaykh, 1978) and forgives if the da'wah targets have not yet received his da'wah (Shaykh, 1978) by continuing to evaluate and analyze to determine a strategy so that the da'wah targets accepts his da'wah.

Da'wah is carried out through communication actions that are built by placing the dai and da'wah targets in an equal position. K.H. Dalhar said "the most difficult thing for humans is a person who is happy with the submission of others to himself and fulfills whatever he wants but he is unable to find his will to fulfill other people, so seek your will to glorify them and never you demand that they glorify you and make no demands except on yourself' (Shaykh, 1978). From this expression, it can be understood that in preaching (da'wah) the dai and the da'wah targets must be placed in an equal position or even more respected the da'wah targets.

A dai does not deliver the da'wah material orally before the da'wah targets asks (Shaykh, 1978). K.H. Dalhar is a humble scholar. One proof of his humility is that he did not want to convey da'wah material orally before the da'wah targets stated that they asked to learn from him. As recounted by Kiai Hamim Jazuli or more familiarly called Gus Miek before studying with Kiai Dalhar, he had often come to Watucongol wearing shorts which according to the community at that time was considered impolite. Kiai Dalhar knew it but that did not make him angry. After coming to Watucongol many times, Gus Miek went to Kiai Dalhar and asked for his guidance. Kiai Dalhar's attitude was inspired by the humble attitude of Shaykh Abi Hasan ash-Syadzili when he was present at the majlis of ulamas (Islamic scholars). He did not want to convey a fatwa before there was a request from the scholars (Shaykh, 1978). After being given the opportunity to deliver the fatwa, he delivered it gently, and full of charm. He was accepted by all levels of society because of his patience, justice, and his understanding of the knowledge of the scholars, of the politics of the rulers and of the wisdom of the wise.

In delivering da'wah, a dai tries to adapt the materials, media and methods to the psychological, sociological, anthropological and intellectual capacities of his da'wah targets (Shaykh, 1978). Psychologically, humans are unique, meaning they are different from one another. Humans have different attitudes and behaviors, and their attitudes and behavior can change in situations that are influenced by external and internal factors. The knowledge about human characteristics is very helpful in the tasks of a dai if da'wah wants to succeed. Human characteristics are absolutely a consideration for a dai in carrying out his da'wah.

Sociologically and anthropologically, Central Java is a tribe that has a diversity of languages, ethnicities, groups, religions and professions which are national assets that will remain united to form harmony in the Indonesian context. In the theological view, the diversity of the phenomena of human life in its various aspects is the will of God which must be addressed with full of wisdom. A dai needs to be aware of this diversity and choose appropriate materials, methods and media.

One of the factors that must be considered by a dai is the intellectual capacity of the da'wah targets. Intellectual is a person's ability to acquire knowledge and practice it in relation to the environment and the problems that arise. Human intellectual levels are genius, normal, low and retarded (Kurniawan, 2021) Genius people can be given complex materials, on the other hand, 
these complex materials cannot be given to those who are intellectually low. Retarded people need special treatment. A dai is expected to be able to serve all people at any intellectual level and try to provide material according to that intellectual capacity.

Kiai Dalhar asserted "If you are in front of scholars then do not talk except discussing knowledge and if you are in front of worshipers and zuhud practitioners then focused your discussion on worshiping and the practices of zuhud and keep their feelings in order to keep them motivated on the good things and make things easy for them which they find difficult. If you are with a shiddiqin, then separate the knowledge that is already known, you will surely get the hidden knowledge" (Shaykh, 1978).

What is interesting to note is that a dai must accept Allah's provisions and forgive fellow servants of Allah (Shaykh, 1978) to maintain harmony with His creatures. This means that when the da'wah has not received a public response or there has not been a significant change in the da'wah targets, then a dai accepts the fact and forgives the da'wah targets' mistakes while he keeps trying to make strategies so that his da'wah is accepted by the da'wah targets.

Theoretically the components or elements of da'wah include dai, da'wah targets, da'wah messages, da'wah methods, da'wah media and da'wah goals (Aziz, 2009). In the concept of Muqtadhal Haal Da'wah these components can be explained as follows:

\section{a. Dai}

Da'wah or preaching is not an easy job. The success in da'wah is largely determined by the competence and attitude of the dai or preacher. Therefore, according to Kiai Dalhar, there are several things that a good dai must possess, among others are a dai feels rich with Allah (Shaykh, 1978), keeps himself from lying, adorns himself by keeping the trust of Allah, opens the heart and always sees Allah, his mouth and soul are always close to Allah, removes the barriers from seeing Allah's attributes and witnesses the essence of Allah's messages, maintains harmony with creatures, equips oneself with knowledge and acts carefully (Shaykh, 1978).

Kiai Dalhar's thoughts are in line with al Gazali's Sufism thoughts (Ghazali, n.d.). According to Kiai Dalhar a dai in general should maintain his behavior to always obey Allah both physically and mentally and in the community he should care for others and the environment. Therefore, the requirements to be a dai are first a dai should support himself with knowledge, always seeks and improves knowledge in order to perfect his deeds and the substance of knowledge given to the community really becomes a light that illuminates and soothes the heart, not a fire that burns and destroys. Second, a dai should have a wara' or wira' $i$ attitude means being careful not to do things that are contrary to the knowledge conveyed in da'wah. According to Nyai Channah Hasanah, the eldest daughter of Kiai Dalhar, Kiai Dalhar is a wira' $i$ scholar; he stopped all of his and his student activities even though they were studying a book (kitab) when the call to prayer was sounded. Then they immediately took ablution water and performed prayers in congregation. Third, a dai should have good manners such as simplicity in gestures, behavior, clothing, language and speech; wisdom and maturity in communication, in the theme selection, in his da'wah material and in the delivery style; 
honesty, namely only conveying the truth, not only justifying himself or blaming others, and what is interesting about Kiai Dalhar's character as a dai according to his daugther is that Kiai Dalhar is very different from people in general. Nyai Chasanah said: "Most people feel smart and want to teach, on the other hand Kiai Dalhar feels he is not capable, and he only wants to give lessons after being requested (Chasanah, 2019).

\section{b. Da'wah Material}

In the discussion above, it has been mentioned that Kiai Dalhar is very careful in preaching, and he always verified his da'wah material. When the knowledge obtained through "kasyaf" contradicts the Qur' an and hadith, they must be abandoned even though it is considered as a truth. If you get knowledge that moves the soul to follow your own desires, then throw it away even though the knowledge is true. Turn to the knowledge of Allah that has been given to the Messenger of Allah, the caliphs, companions, tabi 'in and spiritual teachers who do not follow their own desires, because that will save you from doubts and the tendency to lie (Shaykh, 1978). Thus, in general the material for da'wah according to Kiai Dalhar's concept of thought is the knowledge that comes from the Qur'an and Hadith, the knowledge of Allah given to the Prophet, the Caliphs, companions, tabi in and spiritual teachers who do not follow their own desires.

If mapped based on the classification made by scholars, the substance of the da'wah material presented by Kiai Dalhar includes the totality of Islamic teachings which are covered in three aspects: faith, Islam and ihsan. The three are inseparable links; faith radiates the light of Islam; Islam radiates the light of Ihsan and Ihsan radiates the light of everything. Do not place one dimension higher than another.

Shari'ah is an absolute rule that a servant obeys and his obedience is purely a dedication to the khaliq (the creator) which is decorated with an attitude of full of humility, totality of struggle and full of respect. Allah makes the harmony of human life through sharia, so when heeded this will bring a lot of goodness. Belief in the Creator radiates the power of obeying His rules with the rhythm of noble character.

Islam as a religion contains comprehensive teachings. It does not only regulate a belief system called faith or aqidah, but it also contains a set of values and teachings that regulate human relationship with Allah and the relationship between humans and other creatures called sharia. Islam also contains ethical values (moral) or called Sufism. The relationship between aqidah, sharia and sufism or faith, Islam and ihsan are closely related and cannot be separated from each other.

\section{c. Da'wah Targets}

Da'wah targets are all elements of society with whom we always communicate. Anyone who has the intention of studying with Kiai Dalhar is accepted regardless of intelligence, social status and age (Chasanah, 2019). The interaction between each other is a recommendation and a demand of the Islamic teachings in social life. In a society, the interaction between each other, whether between groups, religious groups, cultures, and ethnicities, is a legal requirement (fardhu ain) that must be enforced in the world anytime and anywhere. Islam as a religion 
rahmatan li al-älamin should be realized in the life of society, nation and state. Here are three positions that every Muslim needs to consider to be used as a basis for interacting and communicating:

a) Recognizing the character and nature of humans who always like to be in groups based on their respective binding elements.

b) Intergroup relations must be cultivated based on mutual understanding and respect

c) Enmity against a group can only be carried out to the group that is clearly hostile to Islam and Muslims. To this group, there is no other attitude except a firm attitude. However, this standard of firmness must be determined in accordance with certain procedures and rules. For example, this firmness should be started from persuasive advice then to harsh punishments; the rules are also about who has the right and the authority to take certain actions, and the types and kinds of actions that may be prosecuted; and others. Thus, prudence, thoroughness and full consideration are things that must be considered.

\section{d. Da'wah Method}

Kiai Dalhar was known as a pious, humble, calm and tawadu' representative (wali) of Allah. According to him, da'wah should be carried out with full of courtesy, touching the heart of the community, respecting the values of local traditions and cultures and paying attention to the conditions and capacities of da'wah targets. Not in a way to scare, threaten and make uncomfortable which is not in line with the teachings of Islam as a religion of peace. Da'wah does not have to be impassioned and convey a message at length, but the most important thing is to make the audience touched and impressed (Chasanah, 2019).

\section{e. Da'wah Media}

According to Kiai Dalhar, da'wah can be delivered orally, through writing, good role models, educational institutions such as pesantren, majlis ta'lim, jam'iyah tarekat, social, cultural, economic and others, most importantly, those media can lead da'wah targets to know Islam and want to learn it and carry out its teachings. This charismatic Kiai has a high tolerance in using da'wah media. Generally, when a scholar has used certain tarekat, such as syadziliyah, they do not allow their students to practice other path. In contrast, Kiai Dalhar allowed Gus Miek, one of his students to compose a series of dhikr in the Jam'iyah Dzikru al-Ghafilin which was different from the series of dhikr in the tarekat Sadziliyah that was practiced by Kiai Dalhar.

\section{f. The Purpose of Da'wah}

Every human activity cannot be separated from what becomes the goal, including da'wah activities. According to Kiai Dalhar the main purpose of da'wah is to invite someone or the community to act to create better conditions, in accordance with religious teachings ( Rabbika) namely knowing God and serving Him so that they can achieve happiness in life in this world and in the hereafter.

K.H. Dalhar provides da'wah material which is always associated with efforts to introduce da'wah targets to the existence of Allah and how they want to serve Him. If you are trying to be 
a sincere person, read the Qur'an, Surah al Ikhlas; If you want your sustenance to run smoothly, read the Qur'an Surah al Falaq; If you want to gain salvation read the Qur'an Surah an-Nas; Above all is the utterance "la iläha illa Allah" which is read in a pure state; If you want your heart to be clean, not difficult, suffering and falling into many sins, read "subhanallah wa bihamdihi subhānallah al-adzim lā ilaha illa Allah" (Shaykh, 1978).

\subsection{K.H. Dalhar's Da'wah Strategy}

The muqtadhal haal da'wah strategy is a detail of da'wah wisdom that really pays attention to the components of da'wah including da'wah targets from the psychological, sociological, anthropological aspects and the intellectual capacity of da'wah targets so that the goals of da'wah are achieved. Based on the concept of Muqtadhal Haal Kiai Dalhar's da'wah thought, it can be formulated the concept of Muqtadhal Haal's da'wah strategy as follows:

\subsubsection{Ilāhiyah (Transcendental) Strategy}

The transcendental strategy is da'wah that bases all its steps and goals on the nuances of divinity. Da'wah is done sincerely as the starting point, the pleasure of Allah as the goal and good deeds as the line of activity. Da'wah targets are gradually brought to salvation, knowing Allah and serving him.

In his work, Kiai Dalhar explained that:

Man will not be saved unless he keeps himself from lying to God, adorns himself by keeping God's trust, opens the heart to always see God, guides his tongue and soul to always draw closer to God, removes barriers to see God's attributes and witness the essence or spirit of the message of God. Truly I have cut off my benefits for myself, how can I not give up the benefits of others for myself while I hope in Allah to benefit others, then what if I do not hope in Allah for myself. Don't rely on your knowledge and your strength, but lean on the power of Allah. Do not convey knowledge with the intention of others to justify you, but convey knowledge so that knowledge will lead you to justify Allah (Shaykh, 1978).

\subsubsection{Irādiyah (Contextual) Strategy}

Contextual strategy is da'wah that is focused on life problems or problems that are being faced by da'wah targets. A dai should try to find the will of his da'wah targets and glorify them (Shaykh, 1978). In Kiai Dalhar's concept of da'wah thought, da'wah is always associated with contextual problems. Kiai Dalhar when introduced Allah to his da'wah targets always associated Allah's role in the problems. As written in his book:

a) If you want to be a sincere person, read the Qur'an, Surah al Ikhlas.

b) If you want your sustenance to run smoothly, read the Qur'an Surah al Falaq.

c) If you want to get salvation, read more of the Qur'an, Surah an-Nas. (Shaykh, 1978)

Kiai Dalhar also emphasized:

If you are in front of the scholars then do not talk except discussing knowledge and if you are in front of worshipers and zuhud practitioners then the discussion is focused on discussing 
worship and asceticism and keep their feelings motivated to the goodness of their opinion and make things easier for them. If you are with the shiddiqin, then separate the knowledge that is already known, you will surely get the hidden knowledge (Shaykh, 1978).

The statement above emphasizes the importance of dai to pay attention to the interests and intellectual capacity of da'wah targets. This statement is the keyword in the concept of Muqtadhal Haal da'wah of Kiai Dalhar. For example, there are several students of Kiai Dalhar who have different abilities and interests. Among them are: first, Kiai Marzuki Giriloyo Imogiri Yogyakarta. He was a scholar who was a worshiper and zuhud practitioner (someone who leaves the pleasures of the world). Kiai Dalhar educated him by studying the books of salaf and wirid/prayer. Second, Kiai Dimyati Banten who studied with Kiai Dalhar and he had mastered the knowledge of the salaf books, so Kiai Dalhar gave him a certificate of the Tarekat Syadziliyah. Third, Kiai Mahrus Ali Lirboyo, a person who was diligent and very disciplined, Kiai Dalhar gave him reinforcement in the study of the books of salaf. Fourth, Gus Miek, who had above average intelligence and his learning techniques, simply observed what his teacher was doing. Kiai Dalhar educated him with devotion and guided him in the ability to read the Qur'an, especially Surah al-Fatihah (Chasanah, 2019).

A dai who convey material that is not appropriate or different from the needs and capacities of the da'wah targets will not receive a response from the da'wah targets. In the physics terminology, the dai and da'wah targets should try to equalize the frequency so that resonance occurs.

\subsubsection{Ațifiyah (Sentimental) Strategy}

Sentimental strategy is da'wah that focuses on aspects of the heart and moves the feelings and minds of da'wah targets. Giving da'wah targets impressive advice, calling with gentleness, or providing satisfactory services are methods developed in this strategy.

Kiai Dalhar explained:

Shaykh Abi Hasan when given the opportunity to speak, he spoke with gentleness and was accepted by all parties because of his greatness and justice and he understood the knowledge of the scholars (ulama), the politics of the rulers and the wisdom of the wise (Shaykh, 1978).

This statement implies that a sentimental strategy can be realized properly if it is supported by the generosity of a preacher's heart, his justice and the ability to understand the knowledge of the ulama, understand the politics of the ruler and the wisdom of the wise.

\subsubsection{Tawazuni (Harmonization) Strategy}

Instinctively humans since they were born have many diverse tendencies that accumulate at two extreme points, right-wrong, good-bad, reward-sin, love-hate and so on. The harmonization strategy is da'wah that focuses on efforts to achieve a balance of the two extreme points that exist in da'wah targets.

Kiai Dalhar wrote as follows:

Eat the best food, drink the most delicious and freshest drinks, sleep in the best of sheet and 
dress in the best of clothes. All of this will lead to the totality of the servant's gratitude to Allah. But keep in mind that the servant will not reach the level of mahabah or love of Allah so that he leaves the pleasures of the world. The performer of the tarekat should release the pleasures of the world from his hands and his heart" (Shaykh, 1978).

Kiai Dalhar, when he saw wrongdoers, did not immediately change them revolutionary, on the contrary, he changed gradually towards harmonization. Islam does not prohibit humans from using luxurious facilities but they must be well aware that all of them are only tools to be more grateful and to know Allah better, and their presence should not make people forget the creator and one will not reach the level of loving Allah as long as that person still loves the world.

The harmonization strategy was applied by Kiai Dalhar in preaching, such as the phenomenon of religious diversity in Muntilan. He responded by dividing the area of religious development between the north of the railway for non-Muslims and the south of the railway for Muslims (Prasiswarto, 2020). Kiai Dalhar forbade burning the Chinese community in Muntilan in the hope that their descendants will follow Islam in the future (Chasanah, 2019). Kiai Dalhar also agreed to be the host of the 14th NU Congress in 1939, hoping to stem the Christianization run by the Dutch (Magelang, 2019). The congress resulted in strategic steps to counter the Dutch steps in Christianization such as establishing educational institutions, hospitals, economic enterprises, and social institutions. It is hoped that Muslims will continue to take advantage of the facilitation provided by the Islamic institutions.

\subsection{The Implementation of the Muqtadhal Haal Da'wah Strategy}

There are four Muqtadhal Haal da'wah strategies as described above, namely transcendental strategies, contextual strategies, sentimental strategies and harmonization strategies. The implementation of each strategy does not stand alone, but one way of da'wah is the implementation of the four strategies, three strategies or two strategies. The transcendental strategy must be embedded in all da'wah methods carried out by a dai and can be collaborated or even integrated with other strategies.

Anthropologically, there are two styles of Islam in Javanese society, namely, santri Islam and syncretic Islam, while others still adhere to Hinduism, Buddhism and Protestant Christianity, Catholicism, Confucianism and several sects of belief (Vannisa, 2018). Kiai Dalhar as a dai (preacher) strived to create ways of da'wah as the implementation of his thoughts and strategies that facilitate and accommodate all types of community diversity so that Islamic teachings can be studied, understood and practiced. The ways of preaching include:

a. Developing Pesantren (Chasanah, 2019) which is the implementation of a transcendental and contextual strategy

b. Composing Prayers in Javanese language (Khalwani, n.d.) which is the implementation of a transcendental and contextual strategy.

c. Da'wah bi al-Hāl (Through Behavior) which is the implementation of a sentimental strategy

d. Developing tarekat which is the implementation of a transcendental strategy 
e. Dhikr Daläil al Khairāt which is the implementation of transcendental strategies

f. Dividing the area of religious development which is the implementation of a harmonization strategy

\section{The Muqtadhal Haal Da'wah and Its Relevance in Modern Society}

Modern society is a group of people living together who influence each other and are bound by norms. Its members have a more advanced, rational and secular orientation of life (Syukur, 2002). Human relationships are based on personal interests. Individualist attitudes are growing rapidly, low social awareness is increasing where people do not know each other and are indifferent. Social relationships are carried out openly in an atmosphere of mutual cooperation when creating reciprocal changes. Modern society is constantly changing and fast. This change is a feature and at the same time a problem that is always faced by modern society because its frequency is getting faster so that it cannot be followed by all levels of society. As a result, tensions and even disintegration are heavier and more traumatic than the disintegration of traditional societies. This change is driven and accelerated by the development of science and technology like the accelerator wheel which moves with increasing intensity (Soekamto, 1993).

Fundamentalism is an inevitability in the modern world (Sirry, 2003). Rationalism and secularism, which are measures of the progress of modern society, have created new problems. Injustice, oppression, exploitation have grown well. The government does not run the agenda of economic improvement, and solve the problems of poverty alleviation, unemployment and unfair and unequal development issues, but instead opens and smoothes the way to capitalism practiced among the ruling elites, therefore widens and expands segments of society that are experiencing economic difficulties. Not to mention the practice of corruption, collusion, nepotism which is difficult to clean. This phenomenon raises the awareness of Muslims to re-establish Islamic values through the da'wah movement (Machendrawati, Nanih, \& Safei, 2001).

The da'wah movements have various platforms. Some appear with a "polite face" but others often appear with a "violent face". The da'wah movement that appears with a violent face cannot be fully blamed, but in fact this da'wah movement is counter-productive and even it has to end before the goal is achieved. Many da'wah movements were forced to be dissolved by the government because they were considered to threaten the existence of the state and disturb the comfort of the community, such as Front Pembela Islam and Hizb ut-Tahrir.

K.H. Dalhar, the scholar who lived during the Dutch colonial and during the struggle for independence period, had a da'wah concept that was successfully applied at that time and could be an alternative to da'wah in the modern era. The concept is called the Da'wah of Muqtadhal Haal which is carried out through communication actions that are built by placing the dai and da'wah targets in an equal position. Dai did not deliver the da'wah material orally before the da'wah targets asked. A dai in delivering da'wah tries to adapt materials, media and methods to the psychological, sociological, anthropological and intellectual capacities of the da'wah targets and forgives if the da'wah targets have not received their da'wah by continuing to 
evaluate and analyze to determine strategies so that the da'wah targets accept their da'wah (Syaikh Dalhar, 1978).

The modern era is the era of democracy. People have the freedom to act, behave, believe and practice their religious teachings. A dai should place an equal position with the da'wah targets. The religious transformation is built through polite, charming and wise communication. The dai does not deliver the da'wah orally before the da'wah targets ask. And what is interesting to note is that when the da'wah has not received a response from the community or there has not been a significant change in the da'wah targets, a dai accepts that fact and forgives the da'wah targets's mistakes while keep trying to make strategies so that his da'wah is accepted. Da'wah cannot be conducted in a harsh, rigid and revolutionary way with an element of coercion in it.

The qualifications that a dai must have and always strive for perfection are feeling rich with Allah and maintaining harmony with creatures; equiping oneself with knowledge and be careful; and having a humble and noble attitude. Modern society is constantly changing and fast. The contemporary knowledge upgrades must be absolutely carried out by a preacher while still upholding the principles of da'wah, namely sincerity as the starting point, the pleasure of Allah as the goal, good deeds as the line of activity, maintaining harmony with creatures and noble character as the pillars.

The modern era is a digital era where all activities that support life have been made easier by technology, including da'wah activities. The innovation of da'wah methods and media is a necessity. The delivery of da'wah in mosques, majlis ta'lim, public recitations, tabligh akbar cannot be completely abandoned, but beyond that a dai can deliver da'wah through social media such as whatshap, facebook, instagram, twiter, line, youtube, etc. A dai can package da'wah messages through the features available in each application, such as short messages, words of wisdom, video recordings, short films that are more interesting and can be accessed by audiences all over the world without time and place limits. This is even more so during the COVID-19 pandemic season that has hit almost all countries in the world and the imposition of restrictions on community activities. All of this is implemented based on transcendental, contextual, sentimental and harmonization strategies in da'wah.

Referring to Habermas critical theory about the concept of Communication (interaction is built on the basis of mutual understanding), it is found that the da'wah strategy applied by Kiai Dalhar to Javanese society includes the interaction process occurred between Kiai Dalhar and his da'wah targets with various social conditions surrounding the da'wah targets through three phases which Habermes called the logical level, the dialectical process level, and the rhetorical process level. At the logical level, Kiai Dalhar and his da'wah targets are looking for arguments consistently. At the level of the dialectical process, Kiai Dalhar and his da'wah targets analyze whether the da'wah message is the right truth. Finally, the stage of the rhetorical process, the da'wah targets voluntarily accepts or rejects the da'wah message. The dialectic of democratic communication in the application of the concept and strategy of the Muqtadhal Haal da'wah of K.H. Dalhar makes KH Dalhar's da'wah more acceptable to the wider community. The success of Kiai Dalhar's da'wah was also influenced by his charismatic figure as a dai who had Karamah and he delivered his da'wah with great politeness, touching hearts, respecting local 
traditions and cultural values and paying attention to the condition of psychological, sociological, anthropological and intellectual capacity of the da'wah targets. Although he was mastering the religious sciences, he still applied cultural methods in preaching. Although he already had one particular tarekat (syadziliyah), he allowed his student, Gus Miek to compose another different series of Dhikr which was named ikru al-Ghäfilin. The dialectic of democratic communication in the application of the concept and strategy of the Muqtadhal Haal da'wah of K.H. Dalhar is very relevant to the characteristics of modern society.

\section{Conclusion}

The Muqtadhal Haal Da'wah of Kiai Dalhar is a da'wah that is carried out through communication actions that are built by placing the dai and da'wah targets in an equal position. A dai did not deliver the da'wah material orally before the da'wah targets asked. A dai in delivering da'wah tries to adapt materials, media and methods to the psychological, sociological, anthropological and intellectual capacities of the da'wah targets and forgives if the da'wah targets have not received their da'wah by continuing to evaluate and analyze to determine strategies so that the da'wah targets accept their da'wah.

Da'wah is carried out in ways that are in accordance with the circumstances of the da'wah targets. Da'wah is not carried out in a rigid and revolutionary way, on the contrary, da'wah is carried out in a polite, gentle, heart-touching manner and proceeds step by step by considering the state of the da'wah targets from the psychological, sociological, anthropological and intellectual capacity aspects. Characters that must be possessed by a dai or preacher are istiqomah with Allah and maintain harmony with creatures, always equip with knowledge, be wira' $i$ and have good character. The substance of da'wah material according to Kiai Dalhar's thought is Islamic teachings contained in the Qur'an and Hadith, the knowledge of Allah given to the Prophet, the caliphs, companions, tabi'in and spiritual teachers who do not follow their own desires. The da'wah material covers the totality of Islamic teachings which are covered in three aspects: faith, Islam and ihsan (Aqidah, Sharia, Sufism). The three are inseparable links, faith radiates the light of Islam, Islam radiates the light of Ihsan and Ihsan radiates the light of everything. Do not place one dimension higher than another dimension. The da'wah targets are all elements of society whom with we always communicate. Anyone who has the intention of studying with Kiai Dalhar is accepted regardless of intelligence, social status and age. Da'wah can be done orally, through writing, good role models, educational institutions such as pesantren, jam'iyah tarekat, social, economic, culture and what is most important that media can lead da'wah targets to know Islam and want to implement its teachings. In the modern era, da'wah can be done through social media through applications with various available features. The purpose of da'wah is to invite someone or society to act to create better conditions for knowing Allah and serving Him.

The da'wah strategy of the Muqtadhal Haal of Kiai Dalhar include the Ilähiyah (transcendental) strategy, the Irädiyah (contextual) strategy, the Atifiyah (sentimental) strategy and The tawäzuni (harmonization) strategy. The implementation of each strategy does not stand alone but collaborates or even integrates and the transcendental strategy becomes the estuary of all strategies. Da'wah is managed in such a way that is adapted to the diversity of da'wah targets 
from the psychological, sociological, anthropological and intellectual capacities.

Modern society with its various inherent phenomena triggers the birth of a fundamentalist da'wah movement with a violent face. This da'wah is in fact counter-productive because it has to end its da'wah movement before the goal is achieved because it is considered to disrupt the existence of the State and the stability of society. The Muqtadhal Haal Da'wah is an alternative in terms of concepts and strategies that are very relevant to modern society because of its dynamic nature, adapting to the conditions of da'wah targets and the dialectic of communication which is built fully democratic without coercion and violence.

\section{Acknowledgments}

The article we wrote "The Muqtadhal Haal Da'wah of K.H. Dalhar and its Relevance in Modern Society" is a report on the research results in completing doctoral studies at the Postgraduate of UIN Sunan Kalijaga. This research is motivated by the many practices of da'wah that were pursued by violence in Indonesia in the 20th century. Kiai Dalhar, a charismatic cleric who lived in 1870 - 1959 AD had the concept and strategy of da'wah whose influence can be felt until now, which the author calls The Muqtadhal Haal Da'wah namely da'wah which is carried out through communication actions that are built by placing the $d a{ }^{\prime} i$ (preacher) and da'wah partners (targets) in an equal position. The $d a{ }^{\prime} i$ does not deliver the da'wah material orally before the da'wah partner asks. The $d a$ ' $i$ in delivering his da'wah tries to adapt the materials, methods and media to the psychological, sociological, anthropological and intellectual capacities of the da'wah partners. Da'wah is not carried out in a hard, rigid and revolutionary way, on the contrary, da'wah is carried out in a polite, gentle, touching manner, and proceeds according to the circumstances of the da'wah partners. This article synchronizes the research results with the life of modern society.

We express our deepest gratitude to Prof. Dr. Dudung Abdurahman, M.Hum. and Dr. H. Andy Dermawan who have spent their time guiding and motivating to complete this article; to Dr. H. Aziz Muslim, M.Pd. who is willing to be a companion in the workshop on Academic Writing and Assistance in Writing Scientific Journal Articles organized by the Postgraduate of UIN Sunan Kalijaga who provides direction and guidance in writing articles. We express our incomparable thanks to Nyai Nur Channah Chasanah, the caretaker of the Pesantren Ad-Dalhariyah Watucongol Muntilan and Mr. Prasiswarto, BSc. the secretary of the Raden Santri Foundation Gunungpring Muntilan who is willing to provide research data. May Allah bless you all, Ameen.

\section{References}

Abdurahman, D. (2019). Metodologi Penelitian Sejarah Islam. Ombak.

Akhdhori, I. (1982). Ilmu Balaghoh Tarjamah Jauhar Maknun.

Aziz, M. A. (2009). Ilmu Dakwah (ke 2). Kencana.

Azra, A. (2002). Islam Nusantara: Jaringan Global dan Lokal. Mizan.

Chasanah, N. C. (2019). Dakwah Kiai Dalhar. 


\section{Macrothink}

International Journal of Social Science Research

ISSN 2327-5510 2022, Vol. 10, No. 1

Geertz, C. (1973). The Interpretation Of Cultures (Basic Book). New York.

Ghazali, I. (n.d.). Ihya’ Ulūmu ad-dīn. Daru Ihya'i al-Kutubi al-Arabiyah.

Hamidi. (2010). Teori Komunikasi dan Strategi Dakwah. UMM Perss.

Hardiman, B. (2009). Menuju Masyarakat Komunikatif. Kanisius.

Ihsani, A. F. A., Febriyanti, N., \& Syakuuroo, S. K. A. (2021). Gus Dur's Multicultural Da'wah And Its Relevance To Modern Society. El-HARAKAH (TERAKREDITASI), 23(1). https://doi.org/10.18860/eh.v23i1.11642

Izudin, A. (2018). Gerakan Sosial Dan Nalar Islam Progresif: Mencari Titik Temu Kerangka Metateori. Jurnal Pemberdayaan Masyarakat: Media Pemikiran Dan Dakwah Pembangunan, 1(2), 254. https://doi.org/10.14421/jpm.2017.012-04

Khalwani. (n.d.). Doa Jawa Mbah Dalhar Watu Congol. Retrieved September 29, 2021, from https://www.muslimina.id/doa-jawa-mbah-dalhar-watu-congol/amp/

Kurniawan, A. (2021). Pengertian Intelektual - Tahap, Faktor, Contoh. Para Ahli. Retrieved from https://www.gurupendidikan.co.id/intelektual/

Ma’sum bin Ali, M. (n.d.). Amsilatu At-Tașrifiyah. Maktabah Salim bin Sa'ad Nabhan.

Machendrawati, N., \& Safei, A. A. (2001). Pengembangan Masyarakat Islam: Dari Ideologi Strategi sampai Tradisi (C. Cuanda (ed.)).

Magelang, P. (2019). Mengapa Muktamar NU ke 14 digelar di Magelang. Suara Nahdliyin. Retrieved from https://www.pcnukabmagelang.or.id/2019/09/mengapa-muktamar-nu-ke-14-digelar-di.html

Muhyiddin, A. dkk. (2014). Kajian Dakwah Multiperspektif. Remaja Rosdakarya.

Munawir, A. W. (n.d.). Al Munawir.

Pirol, A. (2012). Pemikiran Dakwah Nurcholish Madjid. Jurnal Dakwah Tabligh, 13(2), $151-160$.

Prasiswarto. (2020). Dakwah Kiai Dalhar.

Rahmad, M. I. (2005). Arus Baru Islam Radikal: Transmisi Revivalisme Islam Timur Tengah ke Indonesia. Erlangga.

Rosidi. (2013). Dakwah Multikultural di Indonesia: Studi Pemikiran dan Gerakan Dakwah Abdurrahman Wahid. Analisis: Jurnal Studi Keislaman, 13, 482.

Rosidi. (2017). Dakwah Multikultural di Indonesia: Studi Pemikiran dan Gerakan Dakwah Abdurrahman Wahid. Analisis: Jurnal Studi Keislaman, 13(2).

Shaykh, D. (1978). Tasabbuhu aṣ-Ṣaghīr bi al-Akābir fi Żikri Nubźah min Manāqibi Ustaźi al-Akābir.

Sirry, M. A. (2003). Membendung Militansi Agama: Iman dan Politik dalam Masyarakat 


\section{Macrothink \\ International Journal of Social Science Research \\ ISSN 2327-5510 2022, Vol. 10, No. 1}

Modern (S. Mahdi, Sayed; Agung (ed.)). Erlangga.

Soekamto. (1993). Teori Sosiologi Tentang Struktur Masyarakat. Raja Grafindo Persada.

Sugiono. (2009). Metode Penelitian Pendidikan: Pendekatan Kuantitatif, Kualitatif dan $R$ \& D. Alfabeta.

Suhadang, K. (2014). Strategi Dakwah: Penerapan Strategi Komunikasi Dalam Dakwah. Remaja Rosdakarya.

Syukur, A. (2002). Menggugat Tasawuf. Pustaka Pelajar.

Vannisa. (2018). Kebudayaan Jawa Tengah Lengkap Beserta Pakaian dan Rumah Adat. Perpustakaan.id. Retrieved from https://perpustakaan.id/budaya-jawa-tengah/

\section{Copyrights}

Copyright for this article is retained by the author(s), with first publication rights granted to the journal.

This is an open-access article distributed under the terms and conditions of the Creative Commons Attribution license (http://creativecommons.org/licenses/by/4.0/). 